\title{
POTENSI FLY ASH SEBAGAI ADSORBEN DALAM MENYISIHKAN LOGAM BERAT CROMIUM (Cr) PADA LIMBAH CAIR INDUSTRI
}

\author{
Reri Afrianita $^{1}$, Yommi Dewilda ${ }^{2}$ dan Monica Rahayu ${ }^{1}$ \\ ${ }^{1}$ Laboratorium Air Jurusan Teknik Lingkungan Universitas Andalas \\ ${ }^{2}$ Laboratorium Buangan Padat Jurusan Teknik Lingkungan Universitas Andalas \\ Email: reri_anita@ft.unand.ac.id
}

\begin{abstract}
ABSTRAK
Penelitian ini bertujuan untuk melihat kapasitas fly ash sebagai adsorben dalam penyisihan logam kromium $(\mathrm{Cr})$ dalam larutan artifisial. Konsetrasi awal Cr yang digunakan adalah adalah 1,6 $\mathrm{mg} / \mathrm{l}$ merupakan konsentrasi $C r$ tertinggi hasil sampling pada percetakan koran " $X$ " di Kota Padang. Adsorpsi dilakukan secara batch dengan variasi diameter adsorben, berat adsorben, waktu kontak dan kecepatan pengadukan. Dari hasil penelitian didapat kondisi optimum untuk diameter adsorben 0,14-0,075 mm; berat adsorben $1 \mathrm{~g}$; pH adsorbat 2; kecepatan pengadukan $120 \mathrm{rpm}$ dan waktu kontak 60 menit. Pengaruh parameter terhadap kapasitas adsorpsi adalah semakin kecil diameter partikel, maka semakin luas permukaan serapannya, peningkatan kapasitas penyerapan berbanding terbalik dengan jumlah adsorben yang digunakan, pengikatan ion logam Cr sangat efektif pada suasana asam dengan $\mathrm{pH} 2$, kecepatan pengadukan yang rendah menyebabkan kurang efektifnya tumbukan yang terjadi antara adsorben dengan adsorbat dan jika sebaliknya menyebabkan struktur adsorben cepat rusak, dan pada waktu kontak menit ke-60 fly ash telah jenuh atau mencapai titik keseimbangan dalam mengadsorpsi ion logam Cr yang terdapat dalam larutan
\end{abstract}

Kata Kunci: Cromium (Cr), fly ash, Kapasitas Adsorpsi

\begin{abstract}
This study aims to look at the capacity of fly ash as an adsorbent in the elimination of metal chromium (Cr) in an artificial solution. Initial concentration used was $\mathrm{Cr}$ is $1.6 \mathrm{mg} / \mathrm{l}$ is the highest Cr concentration sampling results in newspaper printing industry " $X$ " in the city of Padang. Adsorption was done in batch with variations in diameter adsorbent, adsorbent weight, contact time and stirring speed. Results of the research showed the optimum conditions for the adsorbent from 0.14 to $0.075 \mathrm{~mm}$ in diameter; adsorbent weight of $1 \mathrm{~g}$; adsorbate of $\mathrm{pH} 2$; stirring speed of $120 \mathrm{rpm}$ and contact time of 60 minutes. The influence of parameters on the adsorption capacity is the smaller diameter of the particles, the more the adsorption surface area, adsorption capacity is inversely proportional to the amount of adsorbent used, the binding of metal ions $\mathrm{Cr}$ very effective in acidic condition with a $\mathrm{pH}$ of 2 , a low stirring speed led to a lack of effective collision occurs between the adsorbate and adsorbent otherwise cause rapid deterioration of the adsorbent structure, and the contact time of the 60th minute of fly ash has reached the point of saturation or equilibrium in the adsorbed metal ions contained in the solution of $\mathrm{Cr}$.
\end{abstract}

Keywords : chromium (Cr), fly ash, adsorption capacity 


\section{PENDAHULUAN}

Salah satu industri menengah yang berada di Kota Padang Propinsi Sumatera Barat adalah industri percetakan koran. Limbah cair industri percetakan koran berpotensi untuk mencemari lingkungan air dan tanah yang ada disekitarnya dengan cara melepaskan logam-logam berat (Achmad, 2004). Menurut Setiyono (2004), limbah percetakan koran mengandung logam berat yang terdiri dari logam $\mathrm{Pb}, \mathrm{Cr}, \mathrm{Co}, \mathrm{Mn}$, dan $\mathrm{Sn}$. Berdasarkan penelitian yang dilakukan oleh Sari (2010), dapat diketahui parameter logam berat Kromium yang terkandung dalam limbah industri percetakan koran sebesar $1,42 \mathrm{mg} / \mathrm{L}$ melebihi baku mutu dari Kepmen LH Tahun 1995 yaitu 0,1 mg/L.

Kromium merupakan elemen berbahaya di permukaan bumi dan dijumpai dalam kondisi oksida antara Cr (II) sampai Cr (VI), tetapi hanya kromium bervalensi tiga dan enam yang memiliki kesamaan sifat biologinya. Kromium bervalensi tiga umumnya merupakan bentuk yang umum dijumpai di alam. Dalam material biologis kromium selalu berbentuk tiga valensi, karena kromium enam valensi merupakan salah satu material organik pengoksida tinggi.

Kromium tiga valensi memiliki sifat racun yang rendah dibanding dengan enam valensi. Mukono, (2006) mengatakan bahwa adanya krom menandakan adanya pencemaran limbah industri karena senyawa logam ini tidak terdapat di air yang ada di alam (murni). Pencemaran air oleh garam-garam kromium sangat membahayakan. Keracunan tubuh manusia terhadap kromium $(\mathrm{Cr})$ dapat berakibat buruk terhadap saluran pernafasan, kulit, pembuluh darah, dan ginjal.

Fly ash merupakan residu yang dihasilkan dari tungku pembakaran batubara atau lignite (batubara muda) pada suhu $1100^{\circ} \mathrm{C}$ hingga $1400^{\circ} \mathrm{C}$ (Gatima, et al, 2005). Salah satu adsorben yang relatif murah adalah fly ash.

Keuntungan adsorben berbahan baku fly ash batubara selain biayanya murah juga dapat digunakan baik untuk pengolahan limbah gas maupun limbah cair. Adsorben ini dapat digunakan dalam penyisihan logam berat dan senyawa organik pada pengolahan limbah. Fly ash batubara dapat dipakai secara langsung sebagai adsorben atau dapat juga melalui perlakuan kimia dan fisik tertentu sebelum menjadi adsorben.

Zeolit yang disintesis dari fly ash batubara banyak digunakan untuk keperluan pertanian. Zeolit banyak dikonsumsi dalam pemurnian air, pengolahan tanah, dan lainlain. Zeolit dibuat dengan cara mengkonversi aluminosilikat yang terdapat pada fly ash batubara menjadi kristal zeolit melalui reaksi hidrotermal (Putri, 2008).

\section{METODOLOGI}

Tahapan penelitian terdiri atas:

1. Studi Literatur

Mencakup studi-studi tertentu untuk memperdalam dan mempertajam teori tentang metode penyisihan logam $\mathrm{Cr}$, adsorpsi dan penjelasan fly ash sebagai adsorben.

\section{Pengumpulan Data}

Data yang digunakan dalam penelitian ini adalah data primer. Langkah-langkah dalam pengumpulan data adalah sebagai berikut:

a. Persiapan Adsorben

Tahapan ini mengumpulkan fly ash sebagai adsorben dan pemisahan diameter fly ash yang digunakan.

b. Persiapan Peralatan Penelitian

Bertujuan untuk mempersiapkan alat-alat yang diperlukan dalam penelitian.

c. Survey Lapangan

Bertujuan untuk menentukan lokasi sampling

d. Penentuan Waktu Sampling

Tujuannya untuk menentukan pengambilan sampel pada jumlah produksi koran terbanyak.

e. Sampling

Pada penelitian ini sampel diambil pada satu titik di outlet pipa pembuangan limbah cair.

f. Pembuatan Larutan Artifisial Cr 
Larutan artifisial chromium standard solution telah dipersiapkan dengan konsentrasi $1000 \mathrm{mg} / \mathrm{l}$. Pembuatan larutan artifisial $\mathrm{Cr}$ dengan konsentrasi yang lebih kecil dilakukan dengan mengencerkan larutan induk $\mathrm{Cr} 1000 \mathrm{mg} / \mathrm{l}$ dengan penambahan aquadest.

g. Percobaan Optimasi

Percobaan optimasi dilakukan untuk melihat kapasitas penyerapan adsorben dari lima variasi parameter percobaan yaitu diameter adsorben, berat adsorben, $\mathrm{pH}$ adsorbat, kecepatan pengadukan, dan waktu kontak.

\section{Pengolahan dan Analisis Data}

Setelah percobaan di laboratorium selesai, akan diperoleh data kapasitas penyerapan adsorben pada kondisi optimum berupa parameter diameter adsorben, berat adsorben, $\mathrm{pH}$ adsorben, kecepatan pengadukan dan waktu kontak dalam menyisihkan logam $\mathrm{Cr}$.

\section{HASIL DAN PEMBAHASAN}

Penelitian ini menggunakan fly ash batubara sebagai adsorben untuk menyisihkan logam kromium (Cr) yang terkandung dalam limbah cair industri percetakan koran melalui mekanisme adsorpsi secara batch. Penelitian ini melihat kapasitas penyerapan pada percobaan optimasi dengan variasi diameter adsorben, berat adsorben, $\mathrm{pH}$ larutan adsorbat, kecepatan pengadukan dan waktu pengadukan.

\section{Variasi Diameter Adsorben}

Perbandingan kapasitas penyerapan logam $\mathrm{Cr}$ untuk variasi diameter adsorben dapat dilihat pada Gambar 1 Berdasarkan grafik tersebut, diameter besar yaitu $(>0,3) \mathrm{mm}$ memiliki kapasitas penyerapan sebesar $0,069 \mathrm{mg} / \mathrm{g}$. Ini menunjukkan bahwa pada setiap $1 \mathrm{~g}$ adsorben (fly ash) dapat menyerap 0,069 mg logam Cr. Untuk diameter yang lebih kecil yaitu (0,29-0,15) mm, kemampuan adsorben menyerap logam $\mathrm{Cr}$ adalah sebesar 0,066 mg/g. Kapasitas penyerapan yang paling besar berada pada diameter terkecil $(0,14-0,075) \mathrm{mm}$ yaitu
$0,074 \mathrm{mg} / \mathrm{g}$, sehingga diameter ini sekaligus digunakan sebagai diameter optimum

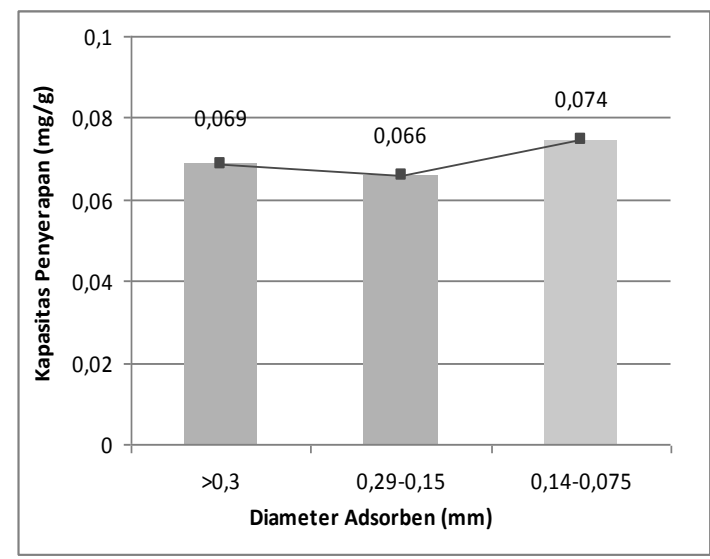

Gambar 1 Perbandingan Kapasitas

Penyerapan Logam $\mathrm{Cr}$ untuk Variasi Diameter Adsorben

Kapasitas penyerapan pada proses adsorpsi tergantung area permukaan yang tersedia untuk interaksi antara larutan dengan permukaan. Dengan kata lain penyerapan dari material yang mempunyai ukuran partikel lebih kecil dapat mengadsorpsi substansi lebih banyak bila dibandingkan dengan partikel berukuran lebih besar (Munaf, 1997 dalam Sasmita, 2007). Dari hasil penelitian diatas, dapat disimpulkan bahwa material yang memiliki diameter yang lebih kecil mempunyai tingkat penyerapan lebih besar dibandingkan dengan diameter adsorben yang lebih besar.

\section{Variasi Berat Adsorben}

Besarnya kapasitas penyerapan logam $\mathrm{Cr}$ yang terjadi pada masing-masing variasi berat adsorben dapat dilihat pada Gambar 2. Dalam volume $100 \mathrm{ml}$ larutan, berat adsorben $0,5 \mathrm{~g}$ dapat menyerap logam $\mathrm{Cr}$ sebesar $0,281 \mathrm{mg} / \mathrm{g}$. Penyerapan logam $\mathrm{Cr}$ selanjutnya terjadi sebesar $0,154 \mathrm{mg} / \mathrm{g}$ untuk berat adsorben $1 \mathrm{~g}$. Untuk berat $2 \mathrm{~g}$, kapasitas penyerapan mulai menurun sebesar $0,052 \mathrm{mg} / \mathrm{g}$. Sama halnya dengan berat adsorben sebelumnya, berat adsorben $3 \mathrm{~g}$ memiliki kapasitas penyerapan yang kecil hingga $0,027 \mathrm{mg} / \mathrm{g}$. 


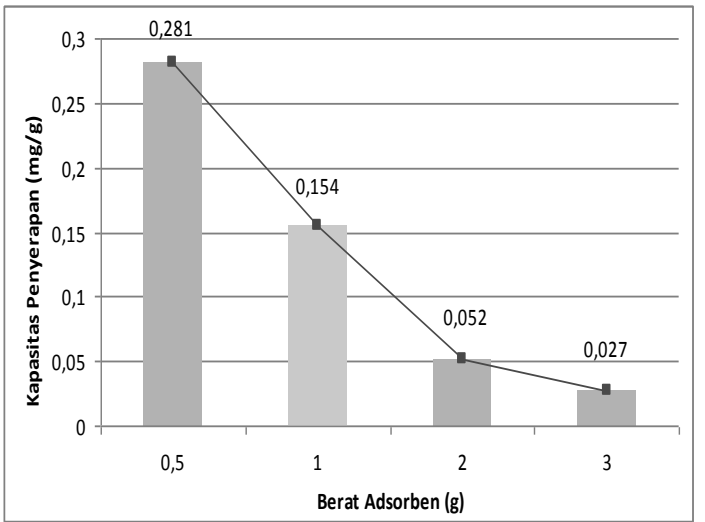

Gambar 2 Perbandingan Kapasitas Penyerapan Logam Cr untuk Variasi Berat Adsorben

Menurut Ahalya, et al (2003), semakin rendah jumlah atau dosis (\% b/v) adsorben yang digunakan maka semakin tinggi kapasitas penyerapannya. Pada dosis yang tinggi kapasitas penyerapan akan semakin rendah, hal ini disebabkan karena adanya interferensi (gangguan) antara ruang pengikatan akibat penggumpalan adsorben. Peningkatan kapasitas penyerapan berbanding terbalik dengan jumlah adsorben yang digunakan. Hal ini disebabkan karena kapasitas penyerapan mengukur banyaknya ion logam yang diserap pada setiap unit berat adsorben.

\section{Variasi pH Adsorbat}

Kapasitas penyerapan logam $\mathrm{Cr}$ untuk variasi $\mathrm{pH}$ dapat dilihat pada Gambar 3 Dari grafik dapat diketahui bahwa nilai terbesar terdapat pada $\mathrm{pH} 2$ dengan kapasitas penyerapan $0,150 \quad \mathrm{mg} / \mathrm{g}$. Kapasitas penyerapan pada $\mathrm{pH} 1$ sebesar $0,148 \mathrm{mg} / \mathrm{g}$, dan yang paling kecil yaitu $\mathrm{pH} 3$ dengan kapasitas penyerapan $0,138 \mathrm{mg} / \mathrm{g}$.

Adanya perubahan efisiensi pada variasi $\mathrm{pH}$ merupakan peran ion-ion $\mathrm{H}^{+}$dan $\mathrm{OH}^{-}$. Menurut Bai \& Abraham (2001), pH adsorbat mempengaruhi gaya elektrostatik ion untuk berhubungan dengan gugus fungsi pada adsorben (Bai \& Abraham, 2001). Pada $\mathrm{pH}$ rendah, anion akan muncul ke permukaan yang disebabkan banyaknya hadir ion $\mathrm{H}^{+}$pada permukaan adsorben. Penyisihan logam $\mathrm{Cr}$ paling optimum terjadi pada $\mathrm{pH} 2$, hal ini disebabkan karena pada pH 2 sejumlah besar ion $\mathrm{H}^{+}$dalam larutan hadir dan akan bereaksi dengan adsorben yang bermuatan negatif dalam larutan. Limbah yang digunakan pada penelitian ini mengandung krom dalam bentuk $\mathrm{Cr}$ (VI) yang distribusinya sangat dipengaruhi oleh pH. Pada $\mathrm{pH} 2, \mathrm{Cr}$ (VI) berupa $\mathrm{Cr}_{2} \mathrm{O}_{7}{ }^{2-}$ berada dalam kesetimbangan dengan $\mathrm{HCrO}_{4}{ }^{-}$ sehingga akan mudah berikatan dengan gugus kation dalam fly ash karena adanya gugus elektrostatis, dimana terjadi kesetimbangan antara ion $\mathrm{H}^{+}$dan ion $\mathrm{OH}^{-}$ dalam adsorben dan adsorbat. Sementara semakin tinggi $\mathrm{pH}$ mendekati 7 pembentukan endapan $\mathrm{Cr}(\mathrm{OH})_{6}$ mulai terjadi, sehingga hal ini akan menurunkan kapasitas adsorpsinya serta efisiensi penyisihan logam kromium (Indrawati, 2009).

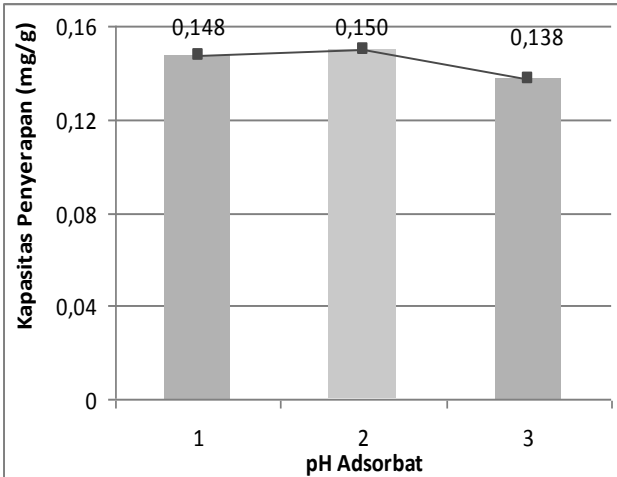

\section{Gambar 3 Perbandingan Kapasitas Penyerapan Logam Cr untuk Variasi pH Adsorbat}

\section{Variasi Kecepatan Pengadukan}

Kapasitas penyerapan pada kecepatan pengadukan $60 \mathrm{rpm}$ dan $90 \mathrm{rpm}$, berada pada titik yang berdekatan dengan nilai secara berurutan adalah $0,060 \mathrm{mg} / \mathrm{g}$ dan 0,074 $\mathrm{mg} / \mathrm{g}$. Untuk kecepatan pengadukan 120 rpm, kapasitas penyerapan yang dihasilkan berada diatas rata-rata variasi sebelumnya yaitu $0,121 \mathrm{mg} / \mathrm{g}$. Sedangkan kecepatan pengadukan $150 \mathrm{rpm}$ dan $180 \mathrm{rpm}$ hanya diperoleh kapasitas penyerapan masingmasing $0,116 \mathrm{mg} / \mathrm{g}$ dan $0,066 \mathrm{mg} / \mathrm{g}$. Untuk lebih jelasnya dapat dilihat pada Gambar 4.

Kecepatan pengadukan menentukan kecepatan waktu kontak adsorben dan adsorbat. Pada kecepatan lambat, maka proses adsorpsi berlangsung lambat pula. Kecepatan pengadukan yang rendah menyebabkan kurang efektifnya tumbukan yang terjadi antara adsorben dengan adsorbat sehingga daya serap bernilai kecil. 
Kecepatan $120 \mathrm{rpm}$ telah efektif mewakili kecepatan optimum karena dengan kecepatan tersebut pergerakan partikel adsorben menjadi efektif sehingga adsorben dapat menyerap adsorbat yang lebih banyak. Untuk kondisi sebaliknya dengan kecepatan pengadukan yang terlalu cepat, maka kemungkinan yang terjadi struktur adsorben cepat rusak, sehingga proses adsorpsi kurang optimal (Alimatun dalam Mulyatna, 2003). Adsorbat yang telah menempel dan membentuk flok nantinya akan kembali pecah karena besarnya kecepatan pengadukan.

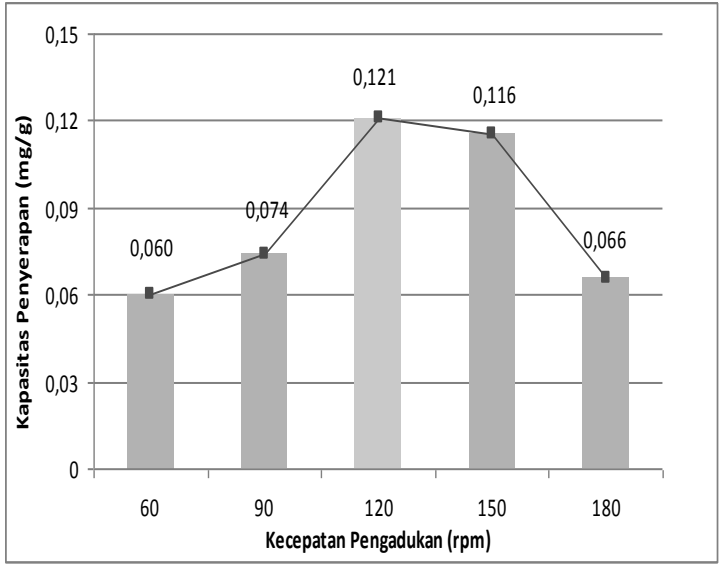

Gambar 4 Perbandingan Kapasitas

Penyerapan Logam Cr untuk Variasi Kecepatan Pengadukan

\section{Variasi Waktu Kontak}

Kapasitas penyerapan dari masing-masing variasi waktu kontak dapat dilihat pada Gambar 5 Untuk waktu pengadukan 30 menit, fly ash dapat menyerap $0,138 \mathrm{mg} / \mathrm{g}$. Kapasitas penyerapan menurun pada waktu kontak 45 menit yaitu sebesar $0,116 \mathrm{mg} / \mathrm{g}$. Untuk waktu kontak selanjutnya kapasitas penyerapan mulai meningkat yaitu pada waktu 60 menit yaitu sebesar $0,146 \mathrm{mg} / \mathrm{g}$. Kapasitas penyerapan kembali menurun pada waktu kontak 75 menit dan 90 menit, yaitu sebesar $0,116 \mathrm{mg} / \mathrm{g}$ dan $0,093 \mathrm{mg} / \mathrm{g}$. Kapasitas penyerapan paling besar terjadi pada waktu kontak 60 menit dan paling kecil terdapat pada waktu kontak 90 menit.

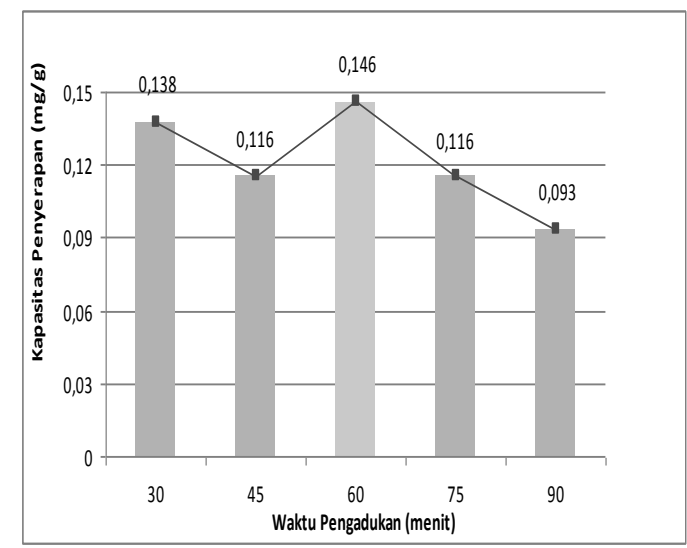

Gambar 5 Perbandingan Kapasitas

Penyerapan Logam Cr untuk Variasi Waktu Kontak

Penyerapan ion logam $\mathrm{Cr}$ dengan menggunakan fly ash menghasilkan bentuk kurva yang dicirikan dengan kapasitas adsorpsi yang cukup tinggi pada waktu kontak 60 menit pertama, kemudian diikuti peningkatan yang relatif lambat hingga posisi kesetimbangan dicapai. Karakteristik ini juga dihasilkan oleh Izanloo \& Nasseri (2005) yang memperkirakan penyisihan ion logam pada adsorben meliputi dua tahap yang berbeda. Besarnya tingkat penyisihan pada beberapa menit pertama (hingga menit ke-60) disebabkan karena adanya mekanisme perpindahan massa dimana ion logam banyak terakumulasi pada lapisan film adsorben dan pada waktu selanjutnya sebagian ion logam mengalami pelepasan dari permukaan adsorben sehingga efisiensi penyisihan menjadi lebih rendah dari pada waktu sebelumnya.

Berdasarkan Gambar 5 dapat dilihat bahwa adsorben masih mampu menyerap logam $\mathrm{Cr}$ hingga menit ke-90. Hal ini disebabkan karena secara umum kapasitas penyerapan semakin meningkat seiring berjalannya proses. Namun peningkatan yang terjadi setelah menit ke-60 cukup kecil. Maka dapat diperkirakan bahwa pada menit ke-60 penyerapan fly ash terhadap logam $\mathrm{Cr}$ hampir mengalami kesetimbangan dinamis antara laju adsorpsi dengan desorpsi (Waranusantigul et al, 2003), yaitu suatu kondisi yang menghasilkan nilai yang tetap dimana ion logam $\mathrm{Cr}$ tidak ada lagi yang diserap maupun larut kembali dari dan ke dalam larutan. 


\section{Percobaan Aplikasi}

Konsentrasi logam kromium yang dihasilkan industri percetakan koran, Padang adalah sebesar 1,6 mg/L. Pemerintah melalui Kepmen LH No. 51 tahun 1995 tentang baku mutu limbah cair bagi kegiatan industri, menetapkan bahwa kadar maksimum logam berat yang diperbolehkan untuk dibuang ke badan air bagi kegiatan industri khususnya untuk logam $\mathrm{Cr}$ adalah $0,1 \mathrm{mg} / \mathrm{L}$. Jika dibandingkan antara konsentrasi logam kromium yang dihasilkan dengan baku mutu yang ditetapkan, maka konsentrasi logam kromium dalam limbah cair industri percetakan koran dinyatakan berada di atas baku mutu dan harus dilakukan pengolahan sebelum dibuang ke badan air penerima. Berdasarkan proses adsorpsi yang dilakukan dengan kondisi optimum yang diperoleh pada percobaan optimasi, yakni pada diameter $(0,14-0,075) \mathrm{mm}$, berat adsorben 1 $\mathrm{g}, \mathrm{pH}$ adsorbat 2, kecepatan pengadukan 120 rpm, dan waktu kontak 60 menit dalam volume $100 \mathrm{ml}$ limbah cair, maka didapat efisiensi penurunan konsentrasi logam $\mathrm{Cr}$ pada sampel limbah industri percetakan koran sebesar $86,111 \%$. Untuk lebih jelas dapat dilihat pada Tabel 1.

Tabel 1 Konsentrasi Parameter Pencemar Limbah Cair Industri Percetakan Koran

\begin{tabular}{|c|c|c|c|c|c|c|c|}
\hline Sampel & $\begin{array}{c}\text { Berat } \\
\text { Adsorben } \\
\text { (g) }\end{array}$ & $\begin{array}{c}\text { pH } \\
\text { Adsorbat }\end{array}$ & $\begin{array}{l}\text { Kecepatan } \\
\text { Pengadukan } \\
\quad(\mathbf{r p m})\end{array}$ & $\begin{array}{l}\text { Waktu } \\
\text { Kontak } \\
\text { (menit) }\end{array}$ & $\begin{array}{c}\mathrm{Ce} \\
(\mathrm{mg} / \mathrm{l})\end{array}$ & $\begin{array}{l}\mathrm{C} \text { in } \\
(\mathrm{mg} / \mathrm{l})\end{array}$ & $\begin{array}{c}\text { Kapasitas } \\
\text { Penyerapan } \\
\text { (mg/g) }\end{array}$ \\
\hline Limbah Industri Percetakan & & & & & & & \\
\hline $\begin{array}{l}\text { Koran } \\
\text { (hari Kamis) }\end{array}$ & & 2 & 120 & 60 & 0,222 & 1,6 & 0,138 \\
\hline
\end{tabular}

limbah industri percetakan koran, konsentrasi logam $\mathrm{Cr}$ mengalami penurunan yaitu dari $1,6 \mathrm{mg} / \mathrm{l}$ menjadi $0,222 \mathrm{mg} / \mathrm{l}$. Dengan efisiensi $86,111 \%$, adsorben dapat menyerap logam $\mathrm{Cr}$ dengan kapasitas 0,138 $\mathrm{mg} / \mathrm{g}$. Hasil pengukuran ini menunjukkan bahwa fly ash sangat efektif digunakan dalam penyisihan kadar logam pada limbah industri percetakan koran, khususnya logam Cr.

Namun konsentrasi akhir yang diperoleh belum memenuhi batas baku mutu. Hal ini kemungkinan disebabkan karena kondisi adsorben fly ash telah mengalami kejenuhan pada menit ke-60. Untuk mendapatkan hasil proses adsorpsi yang konsentrasinya memenuhi baku mutu yang telah ditetapkan, maka perlu dilakukan modifikasi proses melalui adsorpsi secara bertingkat, yaitu dengan mengoperasikannya secara seri atau dengan pengaktifan adsorben terlebih dahulu sebelum digunakan dalam proses adsorpsi

\section{SIMPULAN}

Bedasarkan hasil penelitian mengenai penyerapan logam $\mathrm{Cr}$ pada konsetrasi 1,6 $\mathrm{mg} / \mathrm{l}$ dengan menggunakan fly ash sebagai adsorben disimpulkan:
Pengaruh parameter terhadap kapasitas adsorpsi adalah semakin kecil diameter partikel, maka semakin luas permukaan serapannya sehingga efisiensi penyisihan akan semakin besar, peningkatan kapasitas penyerapan berbanding terbalik dengan jumlah adsorben yang digunakan, pengikatan ion logam $\mathrm{Cr}$ sangat efektif pada suasana asam dengan $\mathrm{pH} 2$, kecepatan pengadukan yang rendah menyebabkan kurang efektifnya tumbukan yang terjadi antara adsorben dengan adsorbat dan jika sebaliknya menyebabkan struktur adsorben cepat rusak, dan pada waktu kontak menit ke-60 fly ash telah jenuh atau mencapai titik keseimbangan dalam mengadsorpsi ion logam $\mathrm{Cr}$ yang terdapat dalam larutan.

Kapasitas penyerapan pada limbah industri percetakkan Koran adalah 0,138 mg/g

\section{DAFTAR PUSTAKA}

Achmad, R. 2004. Kimia Lingkungan. Andi. Yogyakarta.

Bai, Sudha \& Abraham, T. Emilia. 2001. Biosorption of $\mathrm{Cr}$ (VI) from Aqueous Solution by Rhizopus nigricans. Regional Research Laboratory 
(CSIR). Bioresource Technology. Vol 79. No.1

Gatima, Edmond, et al. 2005. Assessment of Pulverised Fly Ash (PFA) as an Ameliorant of Lead Contamineted Soils. Juornal School of Biological Sciences, Plant and Soil Science, University of Aberdeen.

http://www.scipub.org/fulltext/ajes/ajes 13230-238.pdf. Akses:21 Maret 2009) Indrawati, 2009. Aktivasi Abu Layang Batubara dan Aplikasinya Pada Proses Adsorpsi ion Logam Cr dalam Limbah Elektroplating. Jurusan Teknik Kimia. Universitas Gajah Mada.

Izanloo, H \& Nasseri, S. 2005. Cadmium Removal from Aqueous Solution by Ground Pine Cone. Iranian Journal Enviromental Health Science Engineering. Vol 2

Mukono, H.J. 2006. Prinsip Dasar Kesehatan Lingkungan. Jurnal Kesehatan Lingkungan. Jil 2, No.2. Hal 129-142.

Mulyatna, L, dkk. 2003. Pemilihan Persamaan Adsorpsi Isoterm Pada Penentuan Kapasitas Adsorpsi Kulit Kacang Tanah Terhadap Zat Warna
Remazol Golden Yellow 6. Jurnal Infomatek, Jurusan Teknik Lingkungan Fakultas Teknik: Universitas Pasundan.

Sari, Putri Rahmi. 2010. chemical oxygen demand (cod) dengan Menggunakan fly ash Sebagai Adsorben. Tugas Akhir Fakultas Teknik Jurusan Teknik Lingkungan. Universitas andalas. Padang.

Sasmita, Astri. 2007. Penyisihan Logam Besi (Fe) Dari Air Tanah dengan Menggunakan Kulit Jagung (Zea Mays L.) Sebagai Adsorben. Teknik Lingkungan Fakultas Teknik Universitas Andalas Padang.

Setiyono. 2002. Sistem Pengelolaan Limbah B-3 di Indonesia. Kelompok Teknologi Air Bersih dan Limbah Cair, Pusat Pengkajian dan Penerapan Teknologi Lingkungan (P3TL), Deputi Bidang Teknologi Informasi, Energi, Mineral dan Lingkungan, Badan Pengkajian dan Penerapan Teknologi (BPPT).

Waranusantigul, C, et al 2003. Kinetics of basic dye (methylene blue) biosorption by giant duckweed (Spidorela polyrrhiza). Enviromental Pollution Vol.125 Hal 385-392 